\title{
Advanced glycation end products impair the migration, adhesion and secretion potentials of late endothelial progenitor cells
}

\author{
Hong Li ${ }^{\dagger}$, Xiaoyun Zhang ${ }^{\dagger}$, Xiumei Guan, Xiaodong Cui, Yuliang Wang, Hairong Chu and Min Cheng
}

\begin{abstract}
Background: Endothelial progenitor cells (EPCS), especially late EPCS, play a critical role in endothelial maintenance and repair, and postnatal vasculogenesis. Advanced glycation end products (AGEs) have been shown to impair EPC functions, such as proliferation, migration and adhesion. However, their role in the regulation of the production of vasoactive substances in late EPCs is less well defined.

Methods: Passages of 3 5 EPCs, namely late EPCs, were cultured with different concentrations (0 500 $\mu \mathrm{g} / \mathrm{ml})$ of AGEs, and the apoptosis, adhesion and migration were subsequently determined. The release of vasoactive substances, such as stromal cell-derived factor-1 (SDF-1), nitric oxide (NO), prostaglandin $\mathrm{I}_{2}\left(\mathrm{PGI}_{2}\right)$, plasminogen activator inhibitor-1 (PAl-1), tissue plasminogen activator (tPA), and in addition the activity of superoxide dismutase (SOD), were evaluated by ELISA. At the same time, the gene and protein expressions of CXCR4 were assayed by real-time RT-PCR and western-blot.
\end{abstract}

Results: AGEs promoted late EPC apoptosis. Moreover, AGEs impaired late EPC migration and adhesion in a concentration-dependent manner. Accordingly, the production of SDF-1 was decreased by AGEs. Although the CXCR4 expressions of late EPCs were up-regulated for AGE concentrations of 50, 100 or $200 \mu \mathrm{g} / \mathrm{ml}$, a marked decrease was observed for the higher concentration of $500 \mu \mathrm{g} / \mathrm{ml}$. Furthermore, co-culturing with AGEs decreased the levels of $\mathrm{NO}, \mathrm{t}-\mathrm{PA}, \mathrm{PGI}_{2}$, and the activity of SOD but up-regulated the production of PAl-1.

Conclusion: Our data provide evidence that AGEs play an important role in impairing late EPC functions, which could contribute to the development of vascular diseases in diabetes.

Keywords: Endothelial progenitor cells, AGEs, Diabetes, Vasoactive substances

\section{Background}

Diabetes-associated cardiovascular complications, such as atherosclerosis, myocardial infarction and stroke, are among the major causes of patient mortality [1]. It has been shown that loss of endothelial integrity contributes to vascular complications of diabetes [2]. A growing body of evidence indicates that endothelial regeneration and repair do not exclusively rely on the proliferation of local endothelial cells, but also involves bone marrow-derived endothelial progenitor cells (EPCs) [3,4].

EPCs can be isolated from bone marrow, peripheral blood, and umbilical cord blood. Recently, Naito et al even

\footnotetext{
* Correspondence: chengmin1976@wfmc.edu.cn

${ }^{\dagger}$ Equal contributors

Medicine Research Center, Weifang Medical College, Weifang, Shandong 261053, P. R. China
}

identified an endothelial progenitor/stem-like population located at the inner surface of preexisting blood vessels [5]. Actually, EPCs are heterogeneous and can be classified at least as early and late EPCs. The early EPCs appear within 4 to 7 days while the late EPCs develop after 2 to 3 weeks in ex vivo culture systems. They share some endothelial phenotype but are identified with different morphology, proliferation rate and survival feature [6-8]. Currently, most of the studies have mainly focused on early rather than late EPCs $[9,10]$. However, late EPCs, which express a variety of endothelial markers and functionally differentiate into mature endothelial cells, seem to also be important in promoting vascular integrity and neovascularization $[11,12]$.

Advanced glycation end products (AGEs), which are produced by the posttranslation modification of proteins 
via non-enzymatic glycation, accumulate with age and abundantly increase in case of diabetes. They have been shown to be deposited in atherosclerotic lesion, and to promote diabetes-accelerated atherosclerosis [13,14]. Moreover, AGEs impair cell-matrix interactions and growth factor depletion [15]. These evidences suggest that the increased formation of AGEs contributes, at least in part, to the vascular damage in patients with diabetes. Recent studies have shown that AGEs promote EPC apoptosis, inhibit EPC proliferation, and impair EPC functions such as migration, adhesion and tube-forming ability $[16,17]$. However, growing evidence suggest that EPCs can keep endothelial integrity not only by differentiating into mature vascular endothelial cells, but also by secreting the soluble factors including a number of enzymes like matrix protein, growth factors and cytokines [18]. Although it would be interesting to examine the effects of AGEs on the secretion actions of EPCs, only limited studies have been conducted thus far. The present study therefore aims to evaluate the role of AGEs in regulating the release of vasoactive substances in late EPCs, such as $\mathrm{NO}, \mathrm{PGI}_{2}, \mathrm{PAI}-1, \mathrm{tPA}$, together with the activity of SOD. At the same time, we also want to further confirm the effects of AGEs on the apoptosis, migration and adhesion of late EPCs, and to investigate the cellular basis, in particular the role of the SDF-1/CXC4 system.

\section{Methods}

\section{Bone marrow mononuclear cell isolation and culture}

Whole bone marrow was isolated from both the femurs and tibias of Sprague-Dawley rat (150 to $175 \mathrm{~g}$ ) (Weifang medical College, China). The bone marrow mononuclear cells (MNCs) were fractionated by density gradient centrifugation (Histopaque ${ }^{\circledR}-1083$, Sigma, USA). MNCs were plated on dishes precoated with 5\% fibronectin (Roche, Germany), and were maintained in complete EGM-2 medium (supplemented with EGM-2 bullet kit, including $5 \%$ fetal calf serum, recombinant rat VEGF, recombinant human bFGF, Invitrogen, USA). After 4 days in culture, unattached cells were removed by washing with PBS, after which fresh medium was added. Endothelial colonies subsequently appeared (on average 1 colony $/ 10^{7}$ or $10^{8}$ plated mononuclear cells). Highly proliferative endothelial cells grew out from these colonies which then formed a confluent monolayer. Cells under passage 3 5, namely late EPCs, were used for the present study [19]. All animal protocols were approved by the local ethics committee at Weifang Medical College.

\section{EPC identification}

After 7 days of culture, EPCs were characterized by the uptake of 1,1'-dioctadecyl-3,3,3',3'- tetramethylindocarbocyanine-labeled acetylated low density lipoprotein (Dil-acLDL, Molecular probes, USA), and by fluorescein isothiocyanate labeled Ulex europaeus agglutinin (FITCUEA-1, Sigma, USA) staining. In short, the adherent cells were first incubated with Dil-acLDL $(2 \mu \mathrm{g} / \mathrm{ml})$ for $1 \mathrm{~h}$, after which they were fixed in $2 \%$ paraformaldehyde for $10 \mathrm{~min}$, and then stained with FITC-UEA-1 $(10 \mu \mathrm{g} / \mathrm{ml})$ for $1 \mathrm{~h}$. After the staining, the samples were viewed with inverted fluorescence microscope (Leica, Germany). The early EPCs were moreover confirmed by the expressions of CD133 (eBioscience, USA, dilution 1:50) and Sca-1 (Becton Dickinson, USA, dilution 1:50). Cells under passage 3 5, namely late EPCs, were analyzed by FACS (Becton Dickinson, USA) for the expressions of vWF (Sigma, USA, dilution 1:200), VEGFR2 (eBioscience, USA, dilution 1:100), VE-cadherin (Becton Dickinson, USA, dilution 1:400) and PECAM-1(eBioscience, USA, dilution 1:100). The capability of EPCs to form capillary-like tubes in vitro was assessed on Matrigel.

\section{FACS analysis of apoptosis}

Late EPCs were treated with AGEs (Biovision, USA) for $24 \mathrm{~h}$. The range of AGE concentrations used in all experiments was at a dose of $0 \sim 500 \mu \mathrm{g} / \mathrm{ml}$ which is representative of the plasma concentrations of AGEs found in diabetic patients [20]. Approximately $1 \times 10^{6}$ cells were double-stained with Annexin V-FITC and propidium iodide (PI) by using apoptosis detection kit (Becton Dickinson, USA) according to the manufacturer's instructions. Apoptotic cells (Annexin $\mathrm{V}^{+} / \mathrm{PI}^{-}$) were detected by FACS. The apoptotic percentage analysis was performed using Cell-Quest software (Becton Dickinson, USA).

\section{EPC migration assay}

The migratory function of EPCs was evaluated by a modified Boyden chamber (Costar, Cambridge, MA, USA) assay. Briefly, after incubation with serum-free medium for $6 \mathrm{~h}$, EPCs were isolated with trypsin/EDTA, and then incubated with serum-free medium containing AGEs. A total of $4 \times 10^{4}$ EPCs were placed in the upper chamber while medium with VEGF $(50 \mathrm{ng} / \mathrm{ml})$ was placed in the lower chamber. The assays were conducted over a $24 \mathrm{~h}$ incubation period at $37^{\circ} \mathrm{C}$ in an incubator equilibrated with $5 \% \mathrm{CO}_{2}$. The membrane was then washed gently with PBS, and fixed with $4 \%$ paraformaldehyde. Non-migrating cells were gently removed with cotton balls from the upper side of the membrane which was then stained by using 4',6-diamidino-2-phenylindole (DAPI). The migration of EPCs was evaluated by counting the migrated cells in six random high-power $(100 \times)$ microscope fields/well.

\section{EPC adhesion assay}

EPC adhesion assay were performed as previously described [21]. After being treated with different concentrations of AGEs for $24 \mathrm{~h}$, EPCs were washed with PBS, and then gently detached with $0.25 \%$ trypsin/ EDTA. After centrifugation 
and resuspension with serum-free medium, equal cell numbers were seeded on fibronectin coated culture dishes, and incubated for $30 \mathrm{~min}$ at $37^{\circ} \mathrm{C}$. Adherent cells were counted independently in six random high-power $(\times 100)$ microscope fields (HPF)/well by three observers unaware of the treatments.

\section{Assay of the expressions of CXCR4 of EPCs by real-time RT-PCR and western blot}

Total cellular RNA was isolated with TRIzol reagent (Invitrogen, USA) and reverse-transcribed to cDNA using the SYBR ${ }^{\circledR}$ PrimeScript ${ }^{\circledR}$ RT-PCR Kit (Takara, Japan) at $37^{\circ} \mathrm{C}$ for $15 \mathrm{~min}$. Gene expressions were evaluated by SYBR $^{\circledR}$ Premix Ex Taq (Takara, Japan). Rat CXCR4 was amplified with the sense primer 5 '-AGC AGG TAG CAG TGA CCC TCT GA-3' and the anti-sense primer: $5^{\prime}$-GAA GCA GGG TTC CTT GTT GGA GT- 3'. GAPDH (sense primer: 5'-GGC ACA GTC AAG GCT GAG AAT G- 3', anti-sense primer: $5^{\prime}$-ATG GTG GTG AAG ACG CCA GTA- 3') was used as a housekeeping gene, in order to normalize the expression target gene. All primers were used at a final concentration of $0.4 \mu \mathrm{mol} / \mathrm{L}$. The thermal cycling conditions were as follows: 30 seconds at $95^{\circ} \mathrm{C}$ for pre-denaturation, 40 cycles for 15 seconds at $95^{\circ} \mathrm{C}$ for denaturation, 1 minute at $59^{\circ} \mathrm{C}$ for annealing, and 10 seconds at $72^{\circ} \mathrm{C}$ for elongation. At the end of each cycle, the fluorescence emitted by the SYBR Green I was measured. After completion of the cycling process, samples were immediately subjected to a temperature ramp for melting curve analysis. The relative gene expression was analyzed by the $2^{-\mathrm{DDCt}}$ method [22].

Total cellular protein was extracted in $150 \mu \mathrm{l}$ of $1 \times$ SDS loading buffer $(62.5 \mathrm{mmol} / \mathrm{L}$ Tris $-\mathrm{HCl} \mathrm{pH} 6.8$, $2 \%$ SDS, $10 \%$ glycerol, $50 \mathrm{mmol} / \mathrm{L}$ DTT, $0.1 \%$ bromphenol blue) in the presence of 0.1\% EDTA-free protease inhibitor cocktail. Protein was quantified using the bichoninic acid assay (BCA; Pierce Biotechnology, Rockford, IL, USA) according to the manufacturer's instructions. Equal amounts of protein $(50 \mu \mathrm{g})$ were separated through a $12 \%$ SDS-PAGE, and transferred to a PVDF membrane. Membranes were blocked in 5\% milk-TBST, followed by overnight incubation with the primary antibodies against CXCR4. The membranes were then washed with TBST, and incubated with secondary antibody conjugated to HRP (Santa Cruz, USA, dilution 1:1000). Immunoreactive bands were visualized by chemiluminenscence (ECL Amersham Pharmacia).

\section{Assay of secretion actions of EPCs}

To measure the secretion actions of EPCs, the cultures were washed and re-fed with equal amounts of serumfree medium containing different concentrations of AGEs for $24 \mathrm{~h}$. The medium was collected and $10 \times$ concentrated by centrifugation for $20 \mathrm{~min}$ at $5000 \times \mathrm{g}$ at $4^{\circ} \mathrm{C}$ using
Ultrafree-4 centrifugal filter tubes with Biomax-5 membrane(Millipore, USA). The levels of SDF-1, NO, t-PA, PAI-1, PGI 2 , and the activity of SOD in the cell culture supernatants were measured by sandwich enzyme-linked immunosorbent assay (ELISA, RD, USA) according to the manufacturer's instructions. Briefly, standard or testing sample $(50 \mu \mathrm{l})$ was added to the 96-well plate containing immobilized monoclonal antibodies against a kind of factor. After mixing by shaking gently, the plate was incubated at $37^{\circ} \mathrm{C}$ for $30 \mathrm{~min}$. The wells were then washed five times, and incubated with HRP-conjugate reagent at $37^{\circ} \mathrm{C}$ for $30 \mathrm{~min}$. Afterwards, chromogen solution $\mathrm{A}$ and chromogen solution $\mathrm{B}$ were added to each well. The reaction was terminated after 20 min by adding the stop solution. Blank well was taken as zero, and the optical density (OD) was measured with an enzymelinked immunoabsorbent assay reader (Bio-Rad Laboratories, USA).

\section{Statistical analyses}

Unless otherwise indicated, results are reported as mean \pm SE from at least 4 independent experiments. Statistical analyses were performed by one-way ANOVA, followed by Tukey-Kramer post hoc test for multiple comparisons, and $\mathrm{p}<0.05$ was considered to be statistically significant. All data were analyzed using SPSS software (version 15.0; SPSS, Chicago, IL, USA).

\section{Results}

\section{Characterization of bone marrow-derived late EPCs}

The bone marrow-derived MNCs that initially seeded were round (Figure 1A). The distinct colonies formed after $48 \mathrm{~h}$, reaching a peak on the seventh day. The colonies of early EPCs appeared with the round cells in the centers and the typical spindle cells at the peripheries after 7 days (Figure 1B), and were identified as doublepositive for Dil-acLDL uptake and lectin binding affinity (Figure 1D, E, F). Further FACS analysis revealed that the respective expressions of CD133 and Sca-1 were around $24.5 \%$ and $3.3 \%$ in early EPCs (Figure 1G). After 3 4 weeks, the 3 5 passage cells (late EPCs) showed characteristic homogeneity and cobblestone-like morphology similar to mature endothelial cells as previously reported (Figure 1C) [23]. Moreover, the majority of the cells expressed endothelial-specific markers: vWF, VEGFR-2, VE-cadherin and PECAM-1 (Figure 1H) [10]. The angiogenic property of the EPCs was also studied. As shown in Figure 1I and Figure 1J, late, but not early, EPCs successfully formed tubuli like structures on Matrigel.

\section{Effects of AGEs on late EPC apoptosis}

Late EPCs were incubated with different concentrations of AGEs (0, 50, 100, 200 and $500 \mu \mathrm{g} / \mathrm{ml})$ for $24 \mathrm{~h}$. As shown in Figure 2, AGEs induced apoptosis in late EPCs. 

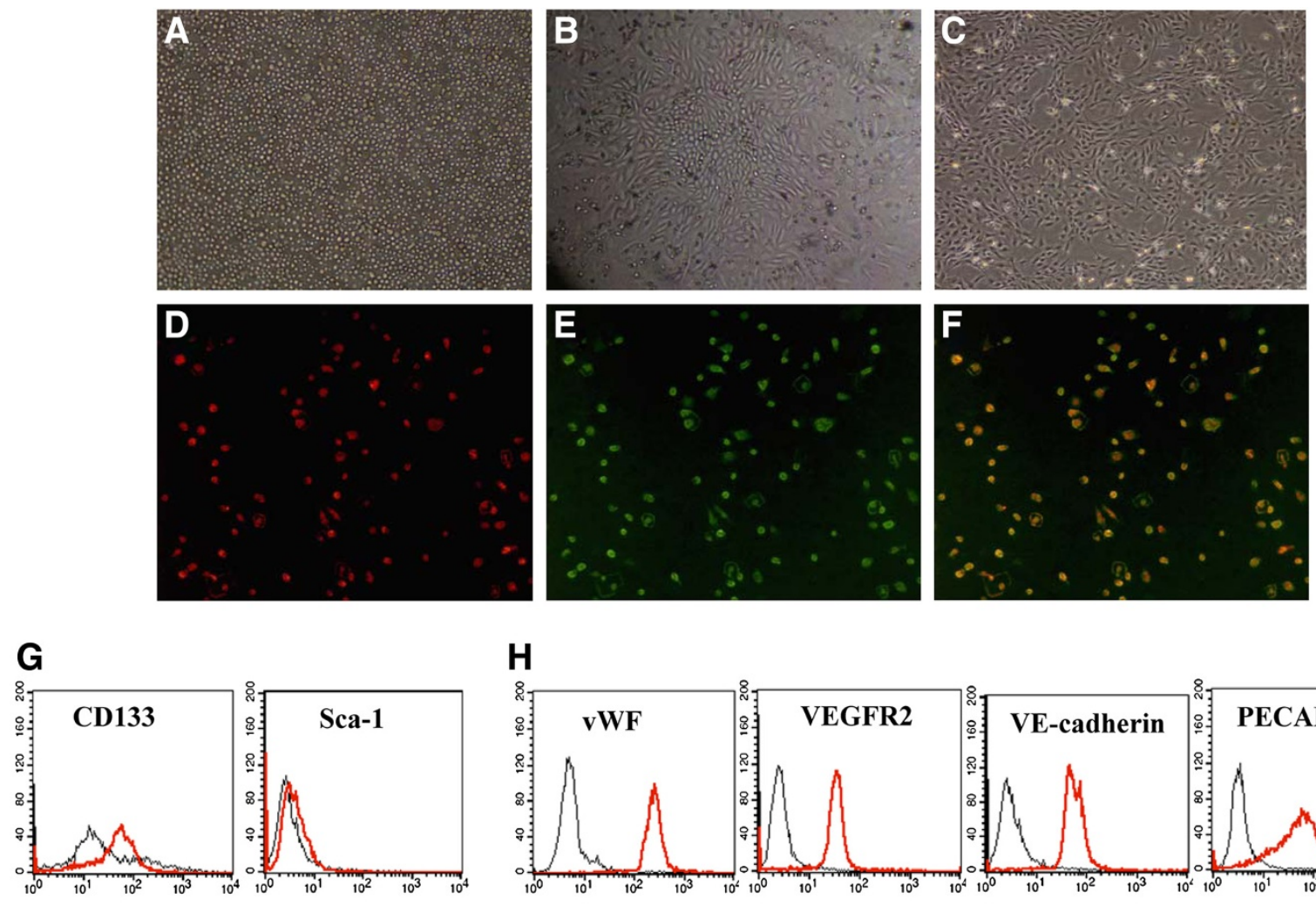

H
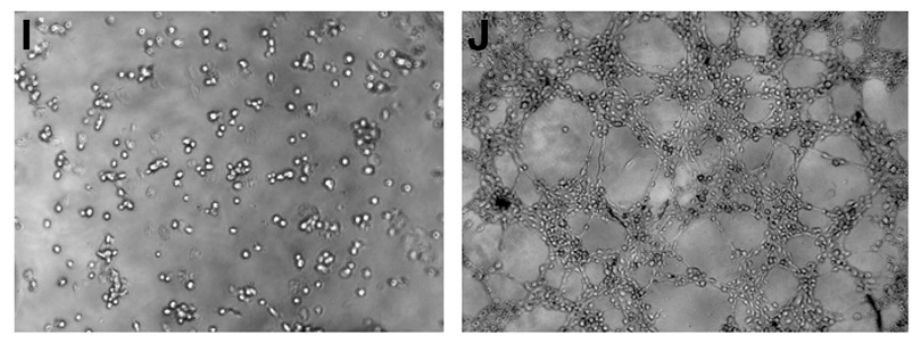

Figure 1 Characterization of EPCs derived from bone marrow. A: MNCs were isolated and plated on fibronectin-coated culture dish on the first day $(100 \times)$. B: Seven days after plating, adherent early EPCs with spindle shape formed clones (100X). C: After 3 4 weeks, the third-fifth passage cells (late EPCS) showed cobblestone-like morphology (100x). D-F: Most early EPCs were shown to simultaneously endocytose Dil-acLDL (red) and bind fluorescein isothiocyanate UEA-1 (lectin) (100x). G: FACS analysis showing the expressions of CD133 and Sca-1 in early EPCs. Plots show isotype controls (black) vs. specific antibody staining (red). H: FACS analysis showing the phenotype of late EPCs using several markers: vWF, VEGFR-2, VE-cadherin and PECAM-1. Plots show isotype controls (black) vs specific antibody staining (red). I-J: Representative images of tubuli like structures formed on Matrigel by early and late EPCs(100x).

The number of apoptotic cells (Annexin $\mathrm{V}^{+} / \mathrm{PI}{ }^{-}$) was observed to increase with higher concentrations of AGEs, reaching a peak at $100 \mu \mathrm{g} / \mathrm{ml}$, and subsequently saturating to a fixed value.

\section{Effects of AGEs on late EPC migration, adhesion and SDF-1/CXCR4 system}

To examine the effects of AGEs on late EPC migration, cells were treated for $24 \mathrm{~h}$ with different concentrations of AGEs in the upper compartment of a Boyden chamber, the lower compartment of which contained EBM-2 medium with VEGF. The AGEs were observed to inhibit late EPC migration in a concentration-dependent manner, with a 4-fold decrease at the maximal concentration tested $(500 \mu \mathrm{g} / \mathrm{ml}$, Figure 3A). Moreover, late EPC adhesion on FN was also significantly reduced in a concentrationdependent manner with adherent cells at less than 38\% of the control value when applied to the maximal dose of AGEs $(500 \mu \mathrm{g} / \mathrm{ml}$, Figure $3 \mathrm{~B})$. To determine whether the impaired migration and adhesion observed in AGEstressed EPCs was related to the SDF-1/CXCR4 system, the release of SDF-1 was measured by ELISA. At the same 


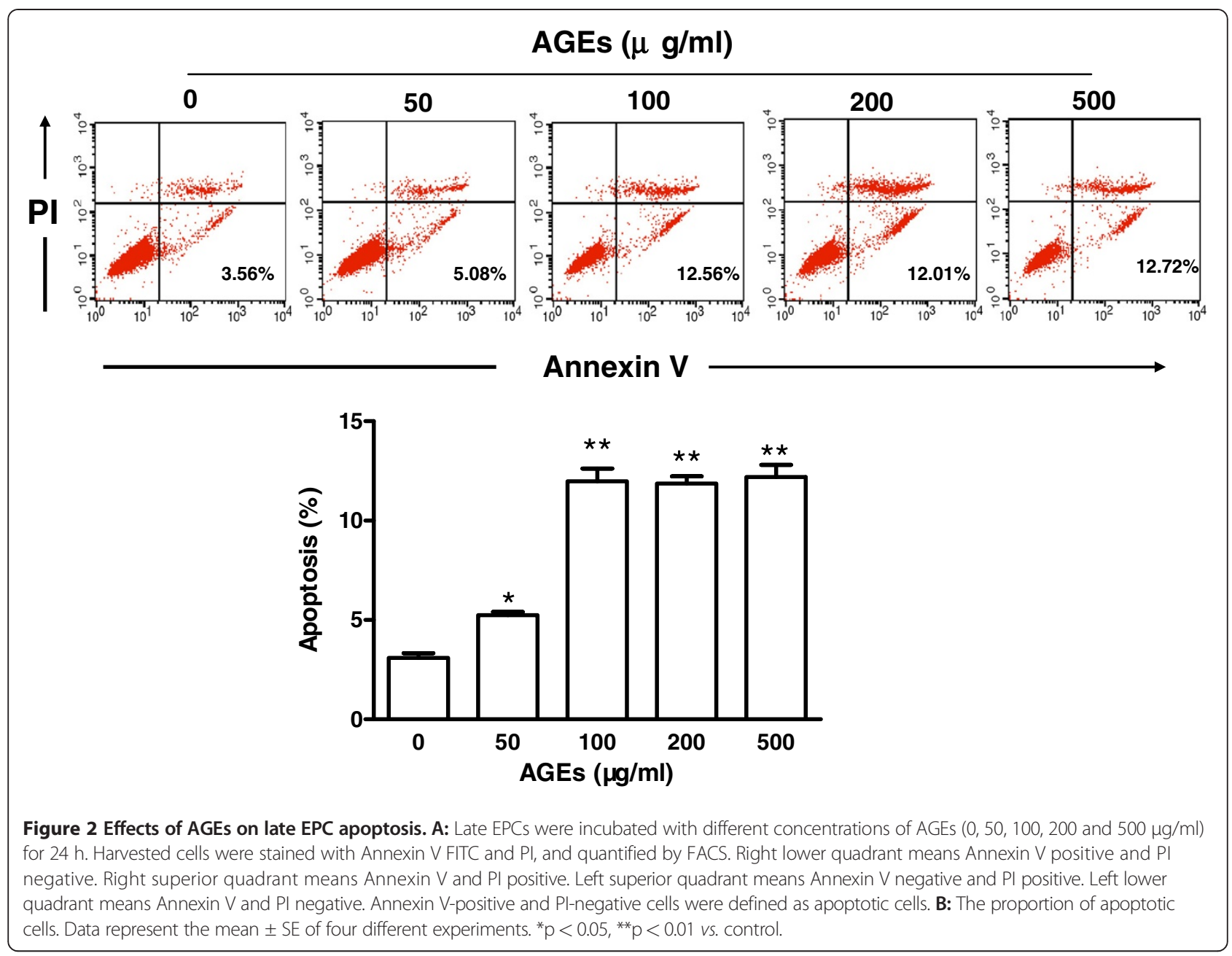

time, the mRNA and protein expressions of CXCR4 were assessed by real-time RT-PCR and western blot, respectively. The AGEs were found to induce a decrease in the SDF-1 secretion in a dose-dependent manner (Figure 3C). However, EPCs treated with 50, 100 and $200 \mu \mathrm{g} / \mathrm{ml}$ of AGEs displayed higher mRNA and protein expressions of CXCR4 than those in the untreated sample. Interestingly, $500 \mu \mathrm{g} / \mathrm{ml}$ of AGEs markedly decreased the CXCR4 mRNA and protein levels of late EPCs (Figure 3D, E).

Effects of AGEs on the productions of the vasodilators, NO and $\mathrm{PGI}_{2}$, in late EPCs

To investigate the effects of AGEs on the productions of the vasodilators in late EPCs, cells were incubated for $24 \mathrm{~h}$ in medium containing different concentrations of AGEs $(0 \sim 500 \mu \mathrm{g} / \mathrm{ml})$. The cultured media were collected, and the amounts of $\mathrm{NO}$ and $\mathrm{PGI}_{2}$ released from the late EPCs were determined by ELISA. Given that $\mathrm{PGI}_{2}$ has a short half-life $(<20$ minutes at physiological $\mathrm{pH})$, levels of 6-keto-prostaglandin $\mathrm{F}_{1 \alpha}$ (6-keto- $\mathrm{PGF}_{1 \alpha}$ ), the $\mathrm{PGI}_{2}$ stable degenerative product, were quantified to evaluate the $\mathrm{PGI}_{2}$ secretion from late EPCs. The results show that the incubation of late EPCs with higher concentrations of AGEs (200 and $500 \mu \mathrm{g} / \mathrm{ml}$ ) significantly decreased the production of NO, compared with that in the control medium. For the lower concentrations of AGEs (50 and $100 \mu \mathrm{g} / \mathrm{ml}$ ), however, no such decrease was observed (Figure 4A). The production of 6-keto-PGF ${ }_{1 \alpha}$ by AGE-stressed EPCs was reduced in a dose-dependent manner. (Figure $4 \mathrm{~B}$ )

\section{Role of AGEs on the activity of SOD in late EPCs}

The bioactivity of SOD was measured in late EPCs. As shown in Figure 5, incubation of cells with higher concentrations of AGEs decreased the SOD activity in EPCs as compared to the control medium. The SOD activity of EPCs was reduced by $25.9 \%$ and $43.7 \%$ in AGE concentrations of 200 and $500 \mu \mathrm{g} / \mathrm{ml}$, respectively.

\section{Influence of AGEs on PAI-1 and t-PA secretions from late EPCs}

Since the balance between PAI-1 and tPA determines the fibrinolytic activity, we also investigated the effects of 

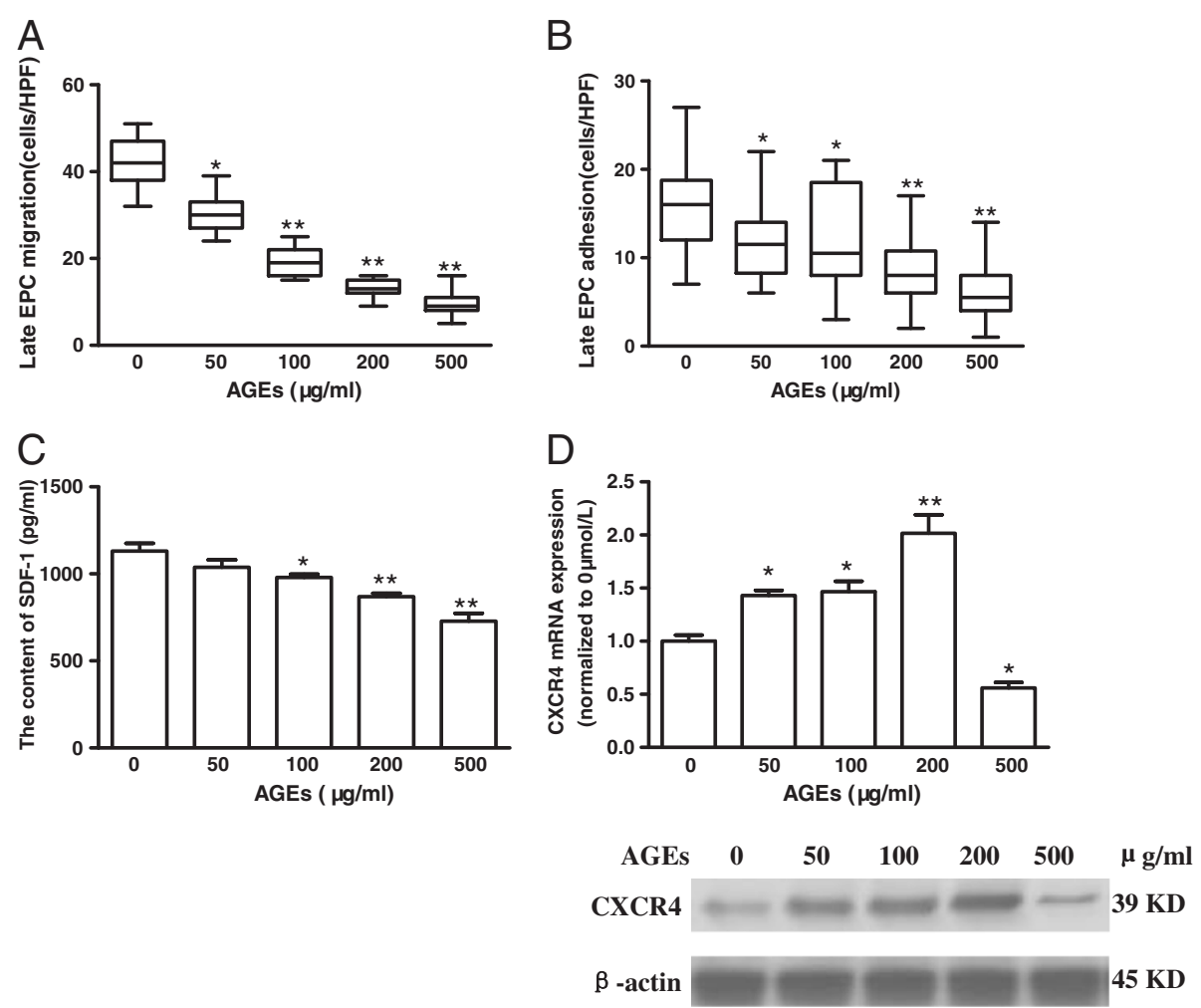

Figure 3 Effects of AGEs on late EPC migration, adhesion and SDF-1/CXCR4 system. Late EPCs were treated with different concentrations of AGEs $(0,50,100,200$, and $500 \mu \mathrm{g} / \mathrm{ml})$ for $24 \mathrm{~h}$. A: The modified Boyden chamber assay was used with VEGF as a chemoattractive factor for late EPC migratory function. The migrated cells were stained with DAPI and counted under microscope. B: EPCs with equal cell numbers were seeded on fibronectin coated culture dishes and incubated for $30 \mathrm{~min}$ at $37^{\circ} \mathrm{C}$. Adherent cells were counted for late EPC adhesion function. C: The supernatants were collected, and the content of SDF-1 was analyzed by ELISA. D: The CXCR4 mRNA expressions were determined using real time quantitative RT-PCR. E: Cell lysates were resolved on 12\% SDS-PAGE, followed by transfer to PVDF membrane. Western blot was carried out with specific antibody for CXCR4, and each band was detected by the ECL reagent. In addition, the $\beta$-actin was analyzed as loading control and protein. Data represent the mean \pm SE of four different experiments. ${ }^{*} p<0.05,{ }^{* *} p<0.01$ vs. control.

AGEs on the productions of PAI-1 and tPA from late EPCs. To this end, late EPCs were exposed to AGEs at concentrations of $0 \sim 500 \mu \mathrm{g} / \mathrm{ml}$ for $24 \mathrm{~h}$, after which they were tested for PAI-1and tPA productions by ELISA. Incubation of late EPCs with $500 \mu \mathrm{g} / \mathrm{ml}$ of AGEs led to a significant decrease in the production of t-PA. However, no statistically significant decrease was observed for low concentrations of AGEs (Figure 6A). In contrast, incubation of late EPCs with $500 \mu \mathrm{g} / \mathrm{ml}$ AGEs led to an increase in the production of PAI-1 (Figure 6B).

\section{Discussion}

AGEs,as a result of chronic hyperglycemia in diabetic patients, have been identified as one of the key risk factors in diabetic-accelerated atherosclerosis [24]. Cell activation, proinflammatory cytokine release and oxidative stress, induced by the interaction of AGEs with their receptors, may lead to endothelial injury and dysfunction $[25,26]$. Growing evidence suggests that EPCs, mobilized from bone marrow and other sites, contribute to the structural integrity of the vasculature, and also restore endothelial dysfunction [3]. Recently, Palombo et al [27] have reported that a significant reduction in the number of EPCs is related to carotid intima-media thickness, an induction of early atherosclerosis in diabetes mellitus. Moreover, the frequency of EPCs in DM patients is negatively correlated with the levels of hemoglobin AIc (HbAIc) [28], and DM patients with satisfactory glycemic control (defined by Hemoglobin A1c, HbA1c $<6.5 \%$ ) have been found to have significantly higher circulating EPC counts [29]. On the contrary, reduction in circulating and soluble form of AGEs by azelnidipine [30] may have beneficial effects on glucose tolerance, insulin sensitivity, the inflammatory state, and number of EPCs [31].

Sun et al [32] have reported that the receptors of AGEs (RAGE) are expressed on EPCs at a low level in normal conditions, and that AGEs significantly increase the RAGE expression, and promote EPC apoptosis in a dose-dependent manner $(50 \sim 300 \mu \mathrm{g} / \mathrm{ml})$. In agreement with those findings, we have here shown that AGEs 
A

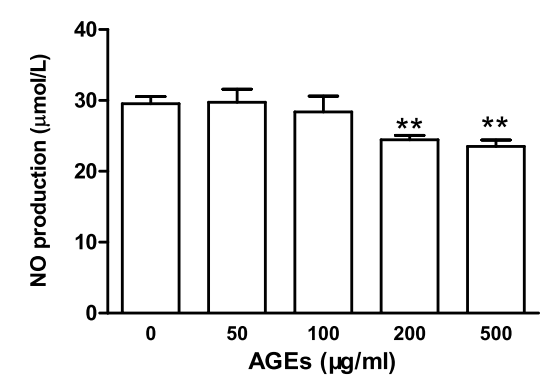

B

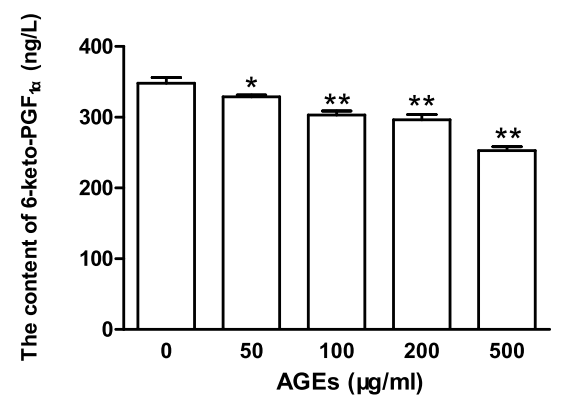

Figure 4 Effects of AGEs on the productions of the vasodilators, $\mathrm{NO}$ and $\mathrm{PGI}_{2}$, in late EPCs. Late EPCS were incubated in medium containing AGEs of concentrations between $0 \sim 500 \mu \mathrm{g} / \mathrm{ml}$ for $24 \mathrm{~h}$, and the cultured media were then collected. A: The amount of NO was determined by ELISA. B: The production of 6-keto-prostaglandin $\mathrm{F}_{1 a}\left(6-\right.$-keto- $\mathrm{PGF}_{1 \mathrm{a}}$ ), the $\mathrm{PG} \mathrm{I}_{2}$ stable degenerative product, was determined by ELISA. Data represent the mean \pm SE of four different experiments. ${ }^{*} p<0.05$, ${ }^{* *} p<0.01$ vs. control.

induce apoptosis in late EPCs, with the apoptosis rate, however, reaching peak at a concentration of $100 \mu \mathrm{g} / \mathrm{ml}$, after which it settles at a constant value even when the AGE concentration is increased further. One possible explanation for the differences between the observed relationship between apoptosis rate and AGE concentration could be the different types of EPCs used in these studies. Late EPCs were used in our study, while Sun et al. used early EPCs in their experiments.

Previous investigations have also demonstrated that AGEs impair EPC functions, such as migration, adhesion and tube formation [16,17]. Our results further confirm that AGEs inhibit migration and adhesion in late EPCs. It is then natural to ask what the mechanisms behind this might be. SDF-1 and its transmembrane receptor CXCR4 play a pivotal role in regulating the trafficking of

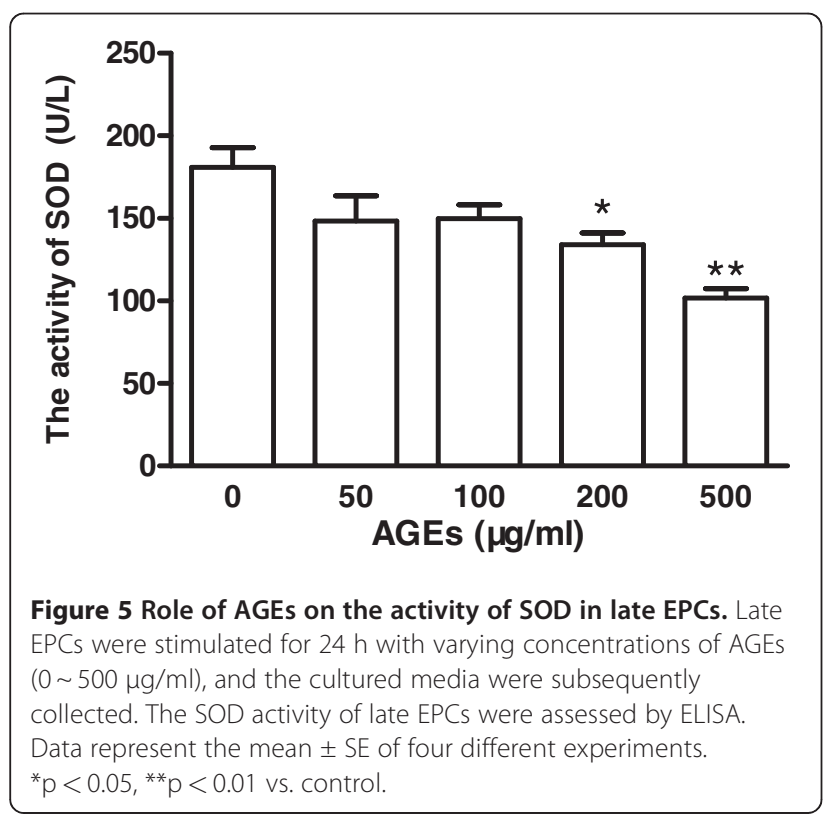

immature stem cells $[33,34]$. Enhanced SDF-1 expression and production is essential for the migration and adhesion of stem cells [35]. It has been shown that ex vivo exposure of EPCs to SDF-1 induces cell migration and adhesion [36]. Moreover, Smadja et al [37] have demonstrated that the angiogenic ability of EPCs may be mediated by an autocrine mechanism involving SDF-1/ CXCR4. To characterize the role of the SDF-1/CXCR4 system in the AGE-induced decrease of the migration and adhesion of late EPCs, we quantified the expressions of SDF-1 and CXCR4. We have observed here that AGEs induce a reduction in SDF-1. Intuitively, one could then expect that AGEs might result in a decrease in CXCR4 as well. In our study, however, we found that AGEs led to the CXCR4 overexpression on the late EPCs, with the overexpression increasing as a function of the AGE concentration only up to a certain point $(200 \mu \mathrm{g} / \mathrm{ml})$, whereas beyond this, at a very high concentration $(500 \mu \mathrm{g} / \mathrm{ml})$, the CXCR4 expression levels were seen to decline. Thus the elevated CXCR4 expression may account for a commentary response to the defective SDF-1 in the AGE stressedEPCs while a high concentration of AGEs can destroy the intrinsic commentary ability of late EPCs.

Due to the fact that the release of vasoactive factors by EPCs also contributes to the vasculature integrity and homeostasis [18], we explored in addition the influence of AGEs on late EPC secretion functions. The results show that AGEs cause a reduction in $\mathrm{NO}, \mathrm{PGI}_{2}$ and tPA. Furthermore, AGEs were identified to decrease the SOD activity of EPCs. At high concentrations, however, the AGEs were seen to increase the secretion of PAI-1 by EPCs.

$\mathrm{NO}$ is a major vasodilator and a key survival factor of the endothelium. The reduction in NO production is possibly contributing to the development of endothelial dysfunction and atherosclerosis in diabetes mellitus [38]. Ozuyaman and colleagues have demonstrated that NO 
A

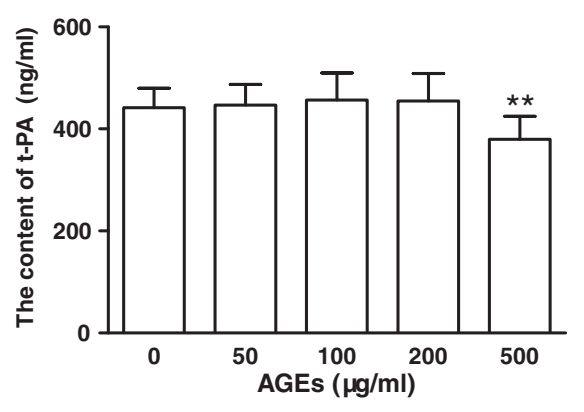

B

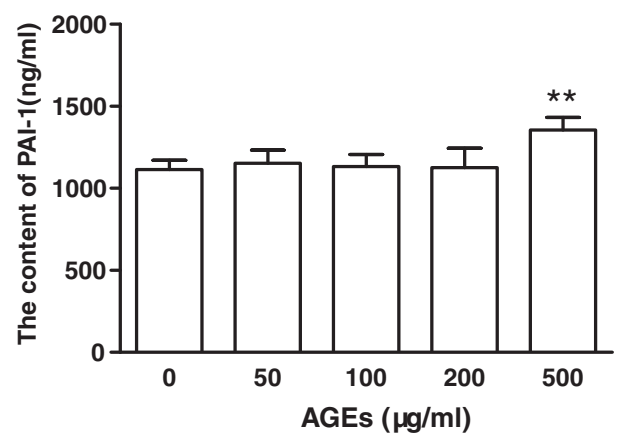

Figure 6 Influence of AGEs on PAI-1 and t-PA secretions from late EPCs. Late EPCs were exposed to AGEs at concentrations of $0 \sim 500 \mu \mathrm{g} / \mathrm{ml}$ for $24 \mathrm{~h}$, after which they were tested for t-PA (A) or PAl-1 (B) production by ELISA. Data represent the mean \pm SE of four different experiments. ${ }^{* *} p<0.01$ vs. control.

can stimulate EPC mobilization from bone marrow stem cell niches to the peripheral circulation [39]. Moreover, it has also been shown that the treatment of EPCs from diabetes patients with an $\mathrm{NO}$ donor drug normalizes their migration [40], and that SDF-1 $\alpha$ restores EPC homing to wounds in diabetic mice through an NO-dependent mechanism [41]. Urao et al have reported that transplantation of autologous EPCs overexpressing eNOS in injured vessels enhances the vasculoprotective prosperities of reconstituted endothelium [42]. Therefore, NO which is produced by the EPCs themselves may create a favorable and optimal environment in regulating their functions. Liang et al [21] reported that the expression of phosphorylated-eNOS is reduced by AGEs in EPCs. In line with this finding, our results show that a $24 \mathrm{~h}$ incubation with AGEs significantly decreases bioavailable NO of late EPCs, which would be one of the determinants of vascular damage in diabetic patients.

In addition to $\mathrm{NO}, \mathrm{PGI}_{2}$ is not only a potent vasodilator contributing to the protection and maintenance of homeostasis in vasculature but also an inhibitor of platelet activation. It has been shown that $\mathrm{PGI}_{2}$ has a direct effect on $\mathrm{EPC}$ functions in an autocrine or paracrine manner through an NO-dependent mechanism, and EPCs from prostacyclin receptor (IP-/-) mice fail to promote re-endothelialization and vessel repair [43]. In the present study, our results show that AGEs impair $\mathrm{PGI}_{2}$ release in cultured EPCs, which may be one of the reasons why the levels of $\mathrm{PGI}_{2}$ is low in the early stages of diabetes [44]. Furthermore, decreased $\mathrm{PGI}_{2}$ has been linked to platelet hyperaggregability, increased adhesiveness, and increased release of PGH2/TXA2 in diabetic patients [45].

It has become evident that the interaction between $\mathrm{NO}$ and $\mathrm{O}_{2}^{-}$is important in the development of endothelial dysfunction [46]. EPCs have high intracellular expression levels of SOD, which can protect them against oxidative stress [47]. Thum et al have reported that increased NAD $(\mathrm{P}) \mathrm{H}$ oxidase activity results in increased $\mathrm{O}_{2}^{-}$generation and reduced $\mathrm{NO}$ bioavailability because $\mathrm{O}_{2}^{-}$inactivates $\mathrm{NO}$ and uncouples eNOS in EPCs [48]. Moreover, the increased $\mathrm{O}_{2}^{-}$is closely associated with the reduced extracellular SOD activity [49]. Thus the addition of SOD may scavenge $\mathrm{O}_{2}^{-}$, increase $\mathrm{NO}$ bioavailability and/or prevent the uncoupling of eNOS in glucose-stressed EPCs [50]. We have here shown that AGEs dose-dependently inhibited SOD activity, which may account for AGEs decreasing bioavailable NO of late EPCs. Thus, AGEs may increase the risk of developing cardiovascular diseases by decreasing the SOD activity of EPCs.

Clinical and experimental studies suggest that thrombus formation and plaque rupture are other major aspects of cardiovascular diseases [51]. t-PA is one of the most important fibrinolytic substances which regulates fibrinolytic activity and prevents thrombus formation. Serving as the primary inhibitor of t-PA, PAI-1 plays a critical role in the regulation of fibrinolysis. The balance between these proteins is known to control the development of thrombosis. A recent study has shown that EPCs can also produce $\mathrm{t}-\mathrm{PA}$, and that the amount secreted by EPCs is comparable to that secreted by mature endothelial cells [52]. Thus we have here also studied the effects of AGEs on the secretion of t-PA and PAI-1 from late EPCs. We have shown that incubation of late EPCs with high concentrations of AGEs leads to a significant decrease in the production of $\mathrm{t}-\mathrm{PA}$, while increasing the production of PAI-1. The different effects of AGEs on t-PA and PAI-1 might lead to an imbalance between them, inducing EPCs to become procoagulative and hypofibrinolytic.

\section{Conclusion}

Taken together, the present study demonstrates that AGEs exert deleterious effects on EPC functions, such as 
migration, adhesion and secretion action. It provides evidence that diabetes via AGEs may contribute to the functional defects of the endothelium in pathological situations by causing the dysfunction of EPCs. Furthermore, these findings give further insight into the complex cellular mechanisms of EPCs for impaired vascular repair and neovasculogenesis in diabetic patients.

\section{Abbreviations}

EPCs: Endothelial progenitor cells; AGEs: Advanced glycation end products; SDF-1: Stromal cell-derived factor-1; NO: Nitric oxide; $\mathrm{PGI}_{2}$ : Prostaglandin $\mathrm{I}_{2}$; PAl-1: Plasminogen activator inhibitor-1; tPA: Tissue plasminogen activator: SOD: Superoxide dismutase; Dil-acLDL: 1,1'-dioctadecyl-3,3,3,3'tetramethylindo- carbocyanine-labeled acetylated low density lipoprotein; FITC-UEA-1: Fluorescein isothiocyanate labeled Ulex europaeus agglutinin; VWF: Von Willebrand factor; VEGFR2: Vascular endothelial growth factor receptor 2; VE-cadherin: Vascular endothelial cadherin; PECAM-1: Platelet endothelial cell adhesion molecule-1.

\section{Competing interests}

The authors declare that they have no competing interests.

\section{Acknowledgements}

This work was supported by the National Natural Science Foundation of China (NO. 30900290), the Natural Science Foundation of Shandong Province (NO. ZR2009CQ027), Program for New Century Excellent Talents in University (NO. NCET-10-0922) and Foundation of Shandong Educational Committee (NO. J09LF06)

We would like to thank Dr. Emil Avsar for critical reading of the manuscript and Prof. Yuguang Gao, the director of stomatological lab in Weifang medical College, for general support.

\section{Authors' contributions}

$H L, X Y Z$ and $M C$ were the principal investigators, involved in designing the study and writing the manuscript. XMG coordinated the study and performed statistical analyses. XDC, YLW and HRC were involved in cell culture, western blot and writing parts of the manuscript. All authors participated in writing the final version of the manuscript.

Received: 14 April 2012 Accepted: 30 April 2012

Published: 30 April 2012

\section{References}

1. Heller GV: Evaluation of the patient with diabetes mellitus and suspected coronary artery disease. Am J Med 2005, 118(Suppl 2):9S-14S.

2. Waltenberger J: Impaired collateral vessel development in diabetes: potential cellular mechanisms and therapeutic implications. Cardiovasc Res 2001, 49(3):554-560.

3. Walter DH, Rittig K, Bahlmann FH, Kirchmair R, Silver M, Murayama T, Nishimura H, Losordo DW, Asahara T, Isner JM: Statin therapy accelerates reendothelialization: a novel effect involving mobilization and incorporation of bone marrow-derived endothelial progenitor cells. Circulation 2002, 105(25):3017-3024.

4. Werner N, Priller J, Laufs U, Endres M, Bohm M, Dirnagl U, Nickenig G: Bone marrow-derived progenitor cells modulate vascular reendothelialization and neointimal formation: effect of 3-hydroxy-3-methylglutaryl coenzyme a reductase inhibition. Arterioscler Thromb Vasc Biol 2002, 22(10):1567-1572.

5. Naito H, Kidoya H, Sakimoto S, Wakabayashi T, Takakura N: Identification and characterization of a resident vascular stem/progenitor cell population in preexisting blood vessels. EMBO J 2012, 31(4):842-855.

6. Rohde E, Malischnik C, Thaler D, Maierhofer T, Linkesch W, Lanzer G, Guelly C, Strunk D: Blood monocytes mimic endothelial progenitor cells. Stem Cells 2006, 24(2):357-367.

7. Brown MA, Wallace CS, Angelos M, Truskey GA: Characterization of umbilical cord blood-derived late outgrowth endothelial progenitor cells exposed to laminar shear stress. Tissue Eng Part A 2009, 15(11):3575-3587.

8. Hur J, Yoon CH, Kim HS, Choi JH, Kang HJ, Hwang KK, Oh BH, Lee MM, Park YB: Characterization of two types of endothelial progenitor cells and their different contributions to neovasculogenesis. Arterioscler Thromb Vasc Biol 2004, 24(2):288-293.

9. Loomans CJ, de Koning EJ, Staal FJ, Rookmaaker MB, Verseyden C, de Boer HC, Verhaar MC, Braam B, Rabelink TJ, van Zonneveld AJ: Endothelial progenitor cell dysfunction: a novel concept in the pathogenesis of vascular complications of type 1 diabetes. Diabetes 2004, 53(1):195-199.

10. Tepper OM, Galiano RD, Capla JM, Kalka C, Gagne PJ, Jacobowitz GR, Levine JP, Gurtner GC: Human endothelial progenitor cells from type II diabetics exhibit impaired proliferation, adhesion, and incorporation into vascular structures. Circulation 2002, 106(22):2781-2786.

11. Sieveking DP, Buckle A, Celermajer DS, Ng MK: Strikingly different angiogenic properties of endothelial progenitor cell subpopulations: insights from a novel human angiogenesis assay. J Am Coll Cardiol 2008, 51(6):660-668.

12. Kawabe-Yako R, Masaaki I, Masuo O, Asahara T, Itakura T: Cilostazol activates function of bone marrow-derived endothelial progenitor cell for re-endothelialization in a carotid balloon injury model. PLoS One 2011, 6(9):e24646.

13. Moriyama T, Kemi M, Okumura C, Yoshihara K, Horie T: Involvement of advanced glycation end-products, pentosidine and N(epsilon)-(carboxymethyl)lysine, in doxorubicin-induced cardiomyopathy in rats. Toxicology 2010, 268(1-2):89-97.

14. Jandeleit-Dahm K, Watson A, Soro-Paavonen A: The AGE/RAGE axis in diabetes-accelerated atherosclerosis. Clin Exp Pharmacol Physiol 2008, 35(3):329-334

15. Stitt AW, Hughes SJ, Canning P, Lynch O, Cox O, Frizzell N, Thorpe SR, Cotter TG, Curtis TM, Gardiner TA: Substrates modified by advanced glycation end-products cause dysfunction and death in retinal pericytes by reducing survival signals mediated by platelet-derived growth factor. Diabetologia 2004, 47(10):1735-1746.

16. Chen J, Song M, YU S, Gao P, Yu Y, Wang H, Huang L: Advanced glycation endproducts alter functions and promote apoptosis in endothelial progenitor cells through receptor for advanced glycation endproducts mediate overpression of cell oxidant stress. Mol Cell Biochem 2010, 335(1-2):137-146.

17. Chen Q, Dong L, Wang L, Kang L, Xu B: Advanced glycation end products impair function of late endothelial progenitor cells through effects on protein kinase Akt and cyclooxygenase-2. Biochem Biophys Res Commun 2009, 381(2):192-197.

18. Urbich C, Aicher A, Heeschen C, Dernbach E, Hofmann WK, Zeiher AM, Dimmeler S: Soluble factors released by endothelial progenitor cells promote migration of endothelial cells and cardiac resident progenitor cells. J Mol Cell Cardiol 2005, 39(5):733-742.

19. Chen YH, Lin SJ, Lin FY, Wu TC, Tsao CR, Huang PH, Liu PL, Chen YL, Chen JW: High glucose impairs early and late endothelial progenitor cells by modifying nitric oxide-related but not oxidative stress-mediated mechanisms. Diabetes 2007, 56(6):1559-1568.

20. Xu B, Chibber R, Ruggiero D, Kohner E, Ritter J, Ferro A: Impairment of vascular endothelial nitric oxide synthase activity by advanced glycation end products. FASEB J 2003, 17(10):1289-1291.

21. Liang C, Ren Y, Tan H, He Z, Jiang Q, Wu J, Zhen Y, Fan M, Wu Z: Rosiglitazone via upregulation of Akt/eNOS pathways attenuates dysfunction of endothelial progenitor cells, induced by advanced glycation end products. Br J Pharmacol 2009, 158(8):1865-1873.

22. Livak KJ, Schmittgen TD: Analysis of relative gene expression data using real-time quantitative PCR and the 2(-Delta Delta $C(T)$ ) Method. Methods 2001, 25(4):402-408.

23. Sakata N, Meng J, Takebayashi S: Effects of advanced glycation end products on the proliferation and fibronectin production of smooth muscle cells. J Atheroscler Thromb 2000, 7(3):169-176.

24. Bro S, Flyvbjerg A, Binder CJ, Bang CA, Denner L, Olgaard K, Nielsen LB: A neutralizing antibody against receptor for advanced glycation end products (RAGE) reduces atherosclerosis in uremic mice. Atherosclerosis 2008, 201(2):274-280.

25. Madonna R, De Caterina R: Cellular and molecular mechanisms of vascular injury in diabetes-part II: cellular mechanisms and therapeutic targets. Vascul Pharmacol 2011, 54(3-6):75-79.

26. Zhou YJ, Yang HW, Wang XG, Zhang $H$ : Hepatocyte growth factor prevents advanced glycation end products-induced injury and oxidative stress through a PI3K/Akt-dependent pathway in human endothelial cells. Life Sci 2009, 85(19-20):670-677.

27. Palombo C, Kozakova M, Morizzo C, Gnesi L, Barsotti MC, Spontoni P, Massart F, Salvi P, Balbarini A, Saggese G, et al: Circulating endothelial 
progenitor cells and large artery structure and function in young subjects with uncomplicated type 1 diabetes. Cardiovasc Diabetol 2011, 10:88

28. Bozdag-Turan I, Turan RG, Turan CH, Ludovicy S, Akin I, Kische S, Arsoy NS, Schneider H, Ortak J, Rehders T, et al: Relation between the frequency of CD34 bone marrow derived circulating progenitor cells and the number of diseased coronary arteries in patients with myocardial ischemia and diabetes. Cardiovasc Diabetol 2011, 10:107.

29. Yue WS, Lau KK, Siu CW, Wang M, Yan GH, Yiu KH, Tse HF: Impact of glycemic control on circulating endothelial progenitor cells and arterial stiffness in patients with type 2 diabetes mellitus. Cardiovasc Diabetol 2011, 10:113.

30. Nakamura T, Sato E, Fujiwara N, Kawagoe Y, Koide H, Ueda Y, Takeuchi M, Yamagishi S: Calcium channel blocker inhibition of AGE and RAGE axis limits renal injury in nondiabetic patients with stage I or II chronic kidney disease. Clin Cardiol 2011, 34(6):372-377.

31. Fukao K, Shimada K, Hiki M, Kiyanagi T, Hirose K, Kume A, Ohsaka H, Matsumori R, Kurata T, Miyazaki T, et al: Effects of calcium channel blockers on glucose tolerance, inflammatory state, and circulating progenitor cells in non-diabetic patients with essential hypertension: a comparative study between Azelnidipine and amlodipine on glucose tolerance and endothelial function - a crossover trial (AGENT). Cardiovasc Diabetol 2011, 10:79

32. Sun $C$, Liang $C$, Ren $Y$, Zhen $Y$, He Z, Wang H, Tan $H$, Pan $X, W u Z$ : Advanced glycation end products depress function of endothelial progenitor cells via p38 and ERK 1/2 mitogen-activated protein kinase pathways. Basic Res Cardiol 2009, 104(1):42-49.

33. Dar A, Kollet O, Lapidot T: Mutual, reciprocal SDF-1/CXCR4 interactions between hematopoietic and bone marrow stromal cells regulate human stem cell migration and development in NOD/SCID chimeric mice. Exp Hematol 2006, 34(8):967-975.

34. Giebel B, Corbeil D, Beckmann J, Hohn J, Freund D, Giesen K, Fischer J, Kogler G, Wernet P: Segregation of lipid raft markers including CD133 in polarized human hematopoietic stem and progenitor cells. Blood 2004, 104(8):2332-2338

35. Vagima Y, Lapid K, Kollet O, Goichberg P, Alon R, Lapidot T: Pathways implicated in stem cell migration: the SDF-1/CXCR4 axis. Methods Mol Biol 2011, 750:277-289.

36. Zemani F, Silvestre JS, Fauvel-Lafeve F, Bruel A, Vilar J, Bieche I, Laurendeau I, Galy-Fauroux I, Fischer AM, Boisson-Vidal C: Ex vivo priming of endothelial progenitor cells with SDF-1 before transplantation could increase their proangiogenic potential. Arterioscler Thromb Vasc Biol 2008, 28(4):644-650

37. Smadja DM, Bieche I, Uzan G, Bompais H, Muller L, Boisson-Vidal C, Vidaud M, Aiach M, Gaussem P: PAR-1 activation on human late endothelial progenitor cells enhances angiogenesis in vitro with upregulation of the SDF-1/CXCR4 system. Arterioscler Thromb Vasc Biol 2005, 25(11):2321-2327.

38. Du XL, Edelstein D, Dimmeler S, Ju Q, Sui C, Brownlee M: Hyperglycemia inhibits endothelial nitric oxide synthase activity by posttranslational modification at the Akt site. J Clin Invest 2001, 108(9):1341-1348.

39. Ozuyaman B, Ebner P, Niesler U, Ziemann J, Kleinbongard P, Jax T, Godecke A, Kelm M, Kalka C: Nitric oxide differentially regulates proliferation and mobilization of endothelial progenitor cells but not of hematopoietic stem cells. Thromb Haemost 2005, 94(4):770-772

40. Segal MS, Shah R, Afzal A, Perrault CM, Chang K, Schuler A, Beem E, Shaw LC, Li Calzi S, Harrison JK, et al: Nitric oxide cytoskeletal-induced alterations reverse the endothelial progenitor cell migratory defect associated with diabetes. Diabetes 2006, 55(1):102-109.

41. Gallagher KA, Liu ZJ, Xiao M, Chen H, Goldstein LJ, Buerk DG, Nedeau A, Thom SR, Velazquez OC: Diabetic impairments in NO-mediated endothelial progenitor cell mobilization and homing are reversed by hyperoxia and SDF-1 alpha. J Clin Invest 2007, 117(5):1249-1259.

42. Urao N, Okigaki M, Yamada H, Aadachi Y, Matsuno K, Matsui A, Matsunaga S, Tateishi K, Nomura T, Takahashi T, et al: Erythropoietin-mobilized endothelial progenitors enhance reendothelialization via Akt-endothelial nitric oxide synthase activation and prevent neointimal hyperplasia. Circ Res 2006, 98(11):1405-1413

43. Kawabe J, Yuhki K, Okada M, Kanno T, Yamauchi A, Tashiro N, Sasaki T, Okumura S, Nakagawa N, Aburakawa Y, et al: Prostaglandin 12 promotes recruitment of endothelial progenitor cells and limits vascular remodeling. Arterioscler Thromb Vasc Biol 2010, 30(3):464-470.
44. Dandona P: Vascular reactivity in diabetes mellitus. Endocrinologia y nutricion: organo de la Sociedad Espanola de Endocrinologia y Nutricion 2009, 56(Suppl 4):12-14

45. Iwase E, Tawata M, Aida K, Ozaki Y, Kume S, Satoh K, Qi R, Onaya T: A cross-sectional evaluation of spontaneous platelet aggregation in relation to complications in patients with type II diabetes mellitus. Metabolism 1998, 47(6):699-705.

46. Cai $\mathrm{H}: \mathrm{NAD}(\mathrm{P}) \mathrm{H}$ oxidase-dependent self-propagation of hydrogen peroxide and vascular disease. Circ Res 2005, 96(8):818-822.

47. He T, Peterson TE, Holmuhamedov EL, Terzic A, Caplice NM, Oberley LW, Katusic ZS: Human endothelial progenitor cells tolerate oxidative stress due to intrinsically high expression of manganese superoxide dismutase. Arterioscler Thromb Vasc Biol 2004, 24(11):2021-2027.

48. Thum T, Fraccarollo D, Schultheiss M, Froese S, Galuppo P, Widder JD, Tsikas D, Ertl G, Bauersachs J: Endothelial nitric oxide synthase uncoupling impairs endothelial progenitor cell mobilization and function in diabetes. Diabetes 2007, 56(3):666-674

49. Turkseven S, Kruger A, Mingone CJ, Kaminski P, Inaba M, Rodella LF, Ikehara S, Wolin MS, Abraham NG: Antioxidant mechanism of heme oxygenase-1 involves an increase in superoxide dismutase and catalase in experimental diabetes. Am J Physiol Heart Circ Physiol 2005, 289(2):H701-H707.

50. Hamed S, Brenner B, Aharon A, Daoud D, Roguin A: Nitric oxide and superoxide dismutase modulate endothelial progenitor cell function in type 2 diabetes mellitus. Cardiovasc Diabetol 2009, 8:56.

51. Hanke $H$, Lenz C, Finking G: The discovery of the pathophysiological aspects of atherosclerosis-a review. Acta Chir Belg 2001, 101(4):162-169.

52. Shirota $T$, He H, Yasui $H$, Matsuda T: Human endothelial progenitor cell-seeded hybrid graft: proliferative and antithrombogenic potentials in vitro and fabrication processing. Tissue Eng 2003, 9(1):127-136.

doi:10.1186/1475-2840-11-46

Cite this article as: Li et al:: Advanced glycation end products impair the migration, adhesion and secretion potentials of late endothelial progenitor cells. Cardiovascular Diabetology 2012 11:46.

\section{Submit your next manuscript to BioMed Central and take full advantage of:}

- Convenient online submission

- Thorough peer review

- No space constraints or color figure charges

- Immediate publication on acceptance

- Inclusion in PubMed, CAS, Scopus and Google Scholar

- Research which is freely available for redistribution 